\title{
成人耳下腺囊胞状リンパ管腫の一症例
}

\author{
西平 茂樹 1$) \cdot$ 山内 博幸 ${ }^{1)} \cdot$ 畺崎 雅和 2 \\ 松崎 全成 3 ・ 江戸 雅孝3
}

\section{Cystic Hygroma of the Parotid Gland in an Adult Man; Report of a Case}

\author{
Shigeki Nishihira and Hiroyuki Yamauchi \\ (Okachi Chuo Hospital) \\ Masakazu Masaki \\ (Akita City Hospital) \\ Zensei Matsuzaki and Masataka Edo \\ (Akita University School of Medicine)
}

\begin{abstract}
A 23 year old man with cystic hygroma of the left side parotid gland was treated surgically. Two years after operation, there was no evidence of recurrence. Because of its invasive nature, it is very difficult to separate the tumor from the facial nerve macroscopically. In order to avoid unnecessary expenses in surgery use of a surgical microscope is recommended.
\end{abstract}

Key words: cystic hygroma, adult, parotid gland, surgical treatment

はじめに

頭頸部領域における脈管系腫瘍の中で, リン 分管腫の $56 \%$ ～90\%は出生時から 5 歳未満に発 見され1)2)，成人の発症例は比較的稀3) 8) である. 今回, 成人耳下腺に発症した輩胞状リンパ管腫 症例を外科的に治療する機会を得た．文献的考 察を加えて報告する。

症例

患者：【, 23歳, 男性.

現病歴 : 平成元年 9 月, 左耳下部から靧角部 におよぶ腫脹に気付いたが放置. 4 力月後腫脹
が増大したため当科受診. 過去に同様な腫脹の 既往無く, また同部の外傷歴および上気道感染 の前駆もなかった.

現症: 初診時, 左側耳下部から上頸部にかけ, 境界不明瞭で脈管系腫瘍を思わせる一様な柔ら かさの腫瘍が約 $70 \times 50 \mathrm{~mm}$ 大で触知された(図 $1 \mathrm{a}, \mathrm{b})$. 顔面皮膚扣よび表情筋の動きに変化 を認めず, 炎症所見, 腫瘍の圧縮, バルサルバ や逆立ちによる大ささの変化等も認められなか った。

単純 Xp：腫瘤に一致する石灰化.

1）秋田県厚生連雄勝中央病院耳鼾咽喉科

2) 秋田市立総合病院耳鼻咽喉科

3）秋田大学医学部耳鼻咽喉科学教室 
CT：耳下腺深葉部分より頸部にかけ，エン ハンスされないひょらたん型の腫瘤が先端を咽 頭側に向け存在した。腫瘤内容は均一であり囊 腫を思わせた（図１c）。
シアロ CT : 耳下腺との境界は, 耳下腺下方 では明瞭であったが，深部やや上方では複雑に 耳下腺内に進入しているような所見が得られた (図 $1 \mathrm{~d}, \mathrm{e})$.
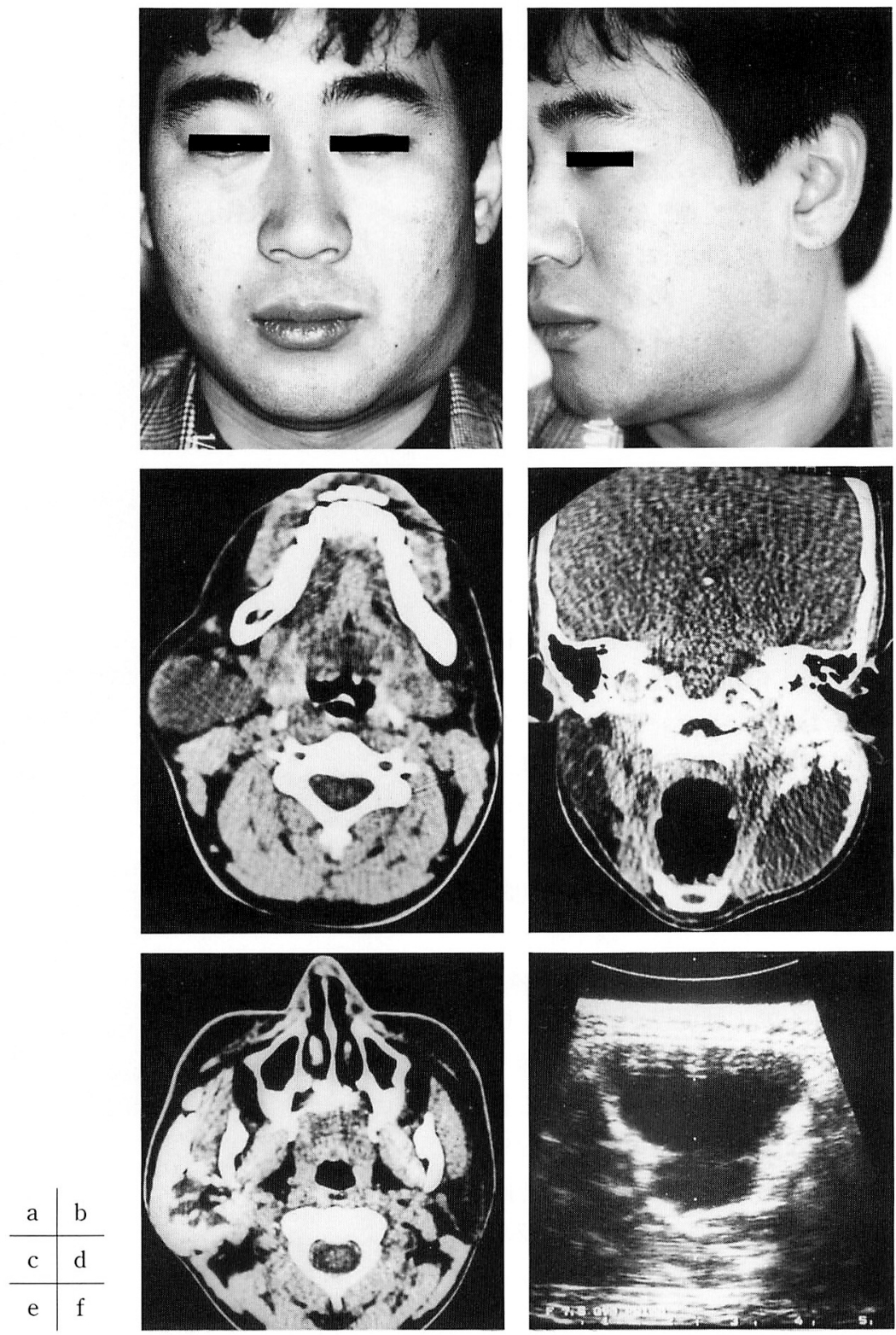

図 1
$\mathrm{a}, \mathrm{b}$; 初診時顔貌
$\mathrm{c} ; \mathrm{CT}$ 水平断像
$\mathrm{d}, \mathrm{e}$; シアロ CT 前額断拈よび水平断像
f ; 超音波検査像 
超音波検查：cysitic パターン扣よび隔壁の 存在が確認された（図 $1 \mathrm{f}$ ).

血管造影：外頸動脈造影を行った結果，腫瘍 は血流に乏しい事が確認された。

穿刺による腫瘤内容の確認は行わなかった。

〈手術所見〉

皮膚切開は標準的なS 状切開とした．耳前部 からの顔面皮膚剝離は腫瘍の前縁近くまでにと ぞめた，腫瘍の周囲組織との癒着は，胸鎖乳突 筋の前縁で軽度に認められたのみで, 顎二復筋 からの剝離は容易であった。型9) 通り顔面神経 本管を露出，それに沿って顔面神経分枝の露出 につとめた．上主枝は前頭枝，頓骨枝の分岐部 分まで剝離されたが，下主枝は腫瘍壁との境界 が不明膫であり，頓枝の分岐さ光確認し得なか った。腫瘍は波動を有し，軟らかく（図 2 a)， 顔面神経本幹の深部から下主枝をまたぐように 存在していた。頸部からの豩離は容易であった ため下方，後方から前上方へ徐々に剥離をす寸 め, 下顎縁枝の末梢側からの剥離を試みたが， 先に中枢側からの剥離が困難になった部位で同 様に腫瘍壁との境界が不明瞭になり, 腫瘍を一 部破損した（内容は透明なリンパ液様であった。 この時点で腫瘍壁の薄さが確認された). 裸眼 による剥離の限界之考兄, 手術用顕微鏡下の剝 離に切り替えた。顕微鏡下では（図 $2 \mathrm{~b}, \mathrm{c}$ ), 神経と腫瘍壁間に僅かに存在する結合織を切断 することが可能であり, 裸眼では剥離不能と思 われた部分であったが比較的容易に神経剝離一 保存が行えた。神経上膜と腫瘍壁が癒着した様 に見えた一部分でも神経上膜を切除して神経そ のものを露出させながら, 顔面神経下主枝の裏 面から腫瘍を剥離, 下方に翻転させながら分枝 する煩枝を保存することがでさた，上主枝方向 に向から煩枝間の吻合枝は切断した. 下主枝末 梢枝は腫瘍により引き延ばされかなり細くなっ ていた。顕微鏡下の剥離を進めていたところ, 残念なことに，先に裸眼で末梢側から神経を剝 離していて腫瘍を破損した部分の近くで下顎縁 枝が結禁切断されていた，その時点で同神経の
䟝離を中止し, 保存し得た神経に注意しながら 腫瘍を完全摘出した。切断された神経は，引さ 延ばされた部分を切断し, 最短距離で縫合した。 神経縫合は，10-0ナイロン系を用い，顕徴鏡 下に神経上膜縫合で 2 針縫合後, フィブリン糊 で補強した10). 保存し得た一部の浅葉で神経の
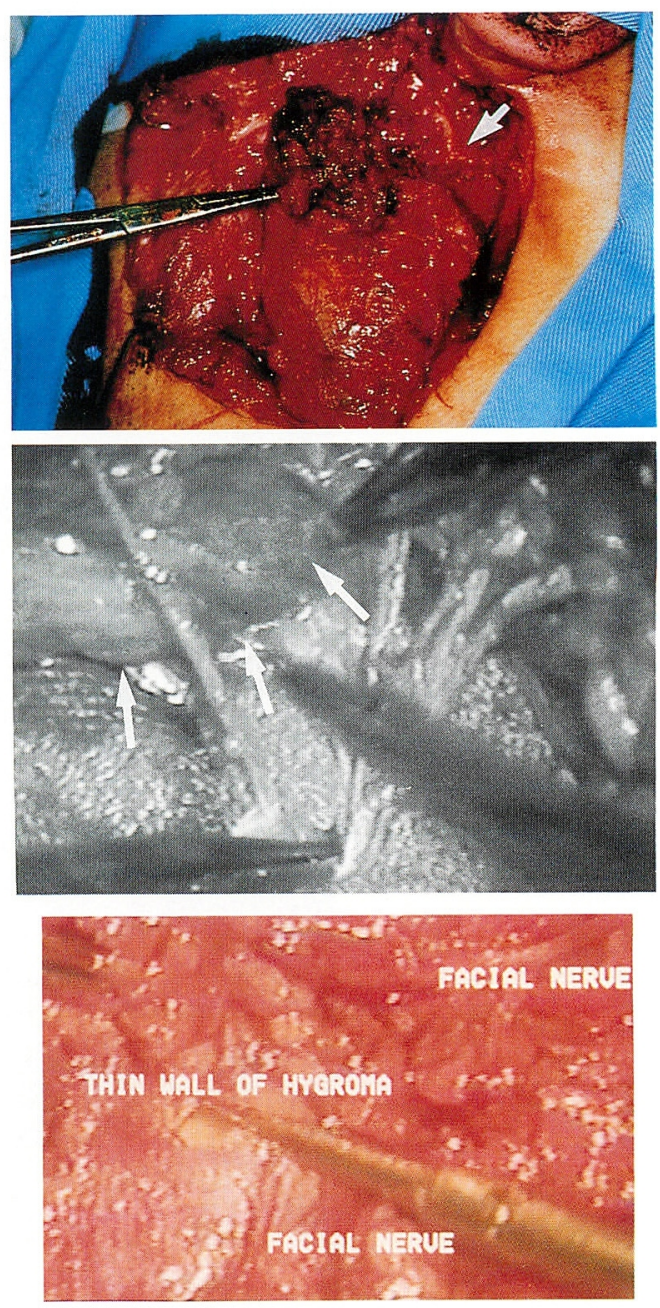

図 2

上; 手術時肉眼所見

腫瘍の耳下腺浅葉部分挔よび顔面神経本管 (↔).

中；手術時顕微鏡下所見 顔面神経枝执よび，腫瘍の深葉部分 (๖).

下; 手術時顕微鏡下所見 薄い腫瘍壁および近接する顔面神経枝. 
露出部分を被覆し，下顎角部の陥凹部に胸鎖入 突筋の一部を翻転させ，ペンローズドレーンを

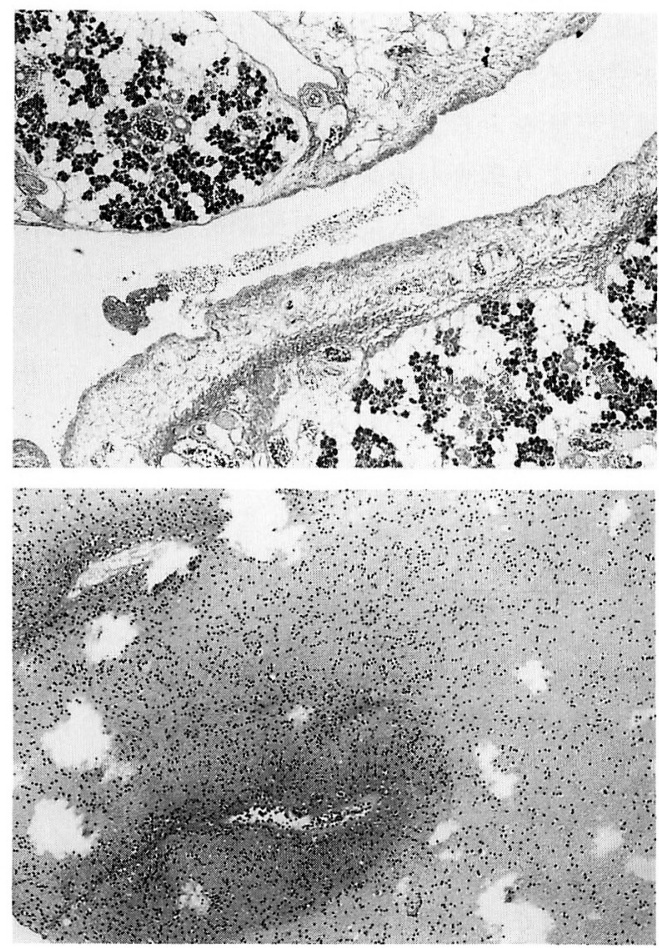

図 3 病理組織所見

上; 正常耳下腺組織内に陷入した薄い腫瘍壁

下；腫瘍内容の細胞はほとんどリンパ球であった

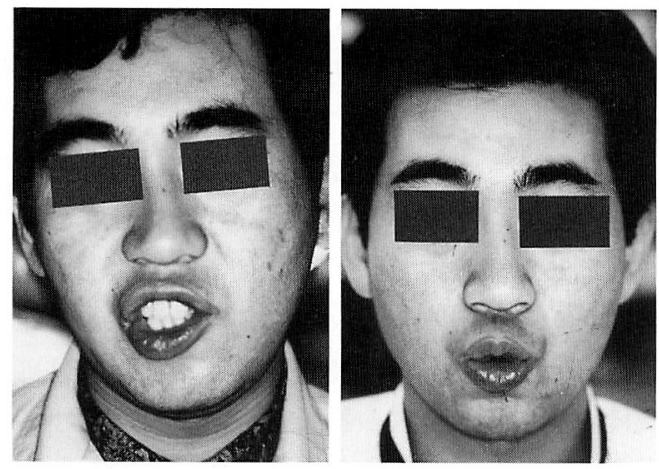

図 4

左 ; 手術直後表情運動

下口唇部分麻痺.

右; 神経縫合術 3 力月後

下口唇の麻痺は完全に回復した。
留置後手術を終了した.

組織所見 : 耳下腺組織内に複雑に入り組んだ,

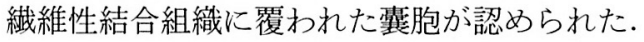
内面は薄い一層の内皮で被われて打り，内容物 の細胞成分のほとんどがリンパ球であった．拡 張したリンパ管が装胞の周囲に多数存在して特 り，リンパ管由来の病変と考えられた，病理診 断は囊胞状リンパ管腫であった（図 $3 \mathrm{a}, \mathrm{b}$ ).

術後経過 : 術後, 下口唇にごく軽度の麻痺が 認められた. 顕微鏡下に処理した煩枝の支配領 域に麻酔はなかったが，口角部分に軽度の麻痺 が認められた（図 $4 \mathrm{a}$ ). 術後10日目に退院し, 外来にて経過観察中であるが，下口唇部分の麻 痺は術後 3 力月目で完全回復した（図 4 b). 手術より 1 年10カ月後の現在再発をみない.

\section{考察}

Redenbacher (1828) によって最初に記載され た“囊胞状リンパ管腫”はとの後 Werner (1843) により“hygroma”之命名され，腫瘍と考兄ら れた。一時期 Rokitansky（1863）らにより, 漿 液性の滲出液の正常組織間での貯留に過ぎない と考えられたが, Virchow (1863)が Wernerの 発見を支持して以来, 再び腫瘍として扱われる ようになった3゙. しかし，その他血管腫，過誤 腫あるいは胎性異常としての奇形と考える報告 があり1)現在に至るも，その発生に関する結論 は得られていない，成人症例に抢㤝る発症機序 に関しても同様に不明だが，幼児期までに発症 しなかった原始リンパ囊がなんらかの機転で急 激に増大するとの考克方がある11).

\section{1. 発生頻度}

発生頻度に関しては，北村は1980年から1983 年の千葉大学退官後の 4 年間で扱った耳下腺腫 痬 170 例中 2 例 $(1.2 \%)^{12)}$, 金子は, 32 年間 (1951 年 1983年) 608 例の耳下腺腫瘍中 18 例 (2.9\%), 非上皮性腫瘍中 $2.3 \%$ のンパ管腫瘍を報告し ている ${ }^{13)}$. 成人の（顔面, 口腔内, 耳下腺を除 いた）頸部リンパ管腫に関する Mayo clinic の 報告によると，1950年～1982年の32年間で32 例3)であった。 その他, 報告の母体が一定して 
いないことから比較は困難であるが，発症年齢 に関係無く15年間に経験された良性腫瘍768例

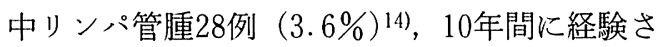
れた2519例の頸部腫瘍中21例 $(0.8 \%)^{15)}, 4054$ 例の出生に対して 1 例の割合16)，25年間に経験 された小肾耳下腺良性腫瘍63例中 2 例17)，9 年 間に経験した大唾液腺腫瘍300例中耳下腺に生 じた 2 例（小児）18などと報告されている.

\section{2. 診断について}

成人例では腫瘤触知以外注とんど無症状に経 過するため診断が困難な場合がある，術前正診 率がわずか $12.5 \%$ （4/32）との報告もある3).

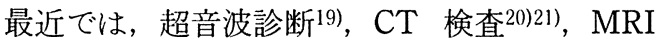

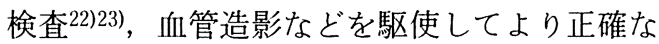
鑑別診断が行えるようになってきた。自験例で はMRI の情報は得られなかったが，発生部位 が耳下腺であったことも幸いしてシアロ CTが 施行され，耳下腺内に複雑に入り込んだ腫瘍の 形態を術前に把握することができた．血管造影 の結果扣よびェンハンス CT の結果よりリンパ 管腫が予想され，超音波検査で cystic パター ンと隔壁の存在が確認されたことから, 耳下腺 内瑣胞状リンパ管腫の診断に迫ることができた.

3 . 囊胞穿刺の診断的価值

それを積極的に推奨する報告と68)，どうし ても診断があいまいな場合に勧められるとする 報告2）とがある。初回の穿刺吸引においては吸 引内容物の性状と細胞診から確診が得られ，そ の診断的価值は大きいと考えられるが，囊内に 出血があった場合や 2 回目の穿刺からは血液の 混入が多くなりその診断価値は減少する。世良 ら 24 ） は，巨大豊胞状リンパ管腫の $55 \%$ ，その 他のリンパ管腫の $36 \%$ に血清内容を認めている. 出血や感染の危険を考慮して術直前に施行する ことを勧める報告25) もある. 実際の手術に際 しては, 腫瘍と周囲組織との関係および易出血监 性か否かの情報が最も重要であり, 自験例に関 しては確診を得るための穿刺を必須なものとは 考えなかった。
4. 治療について

成人の場合, 手術摘出が第一選択となる. 腫 瘍は比較的よく被包化されているが神経血管系 に癒着する傾向があり, 注意深い剥離操作が要 求される3). 自験例のように耳下腺組織内で複 雑な形態をとるような症例の場合, 顕微鏡下の 手術がより確実な成果を生むと考える. 手術成 績に関しては, 成人症例の長期経過観察報告に よると，28症例中 6 例 $(21 \%)$ に再発がみられ， その再発時期はほとんどの症例で 1 年以内であ った ${ }^{344)}$. 再発の生じる頻度は一般に高い。根 治を目的としたと思われた手術後の再発率でも， $27 \%^{2)} ， 8 \%{ }^{3)}$ である. 不完全あるいは切除症 例の再発率はより高率2)である.

小児症例では，摘出手術を第一選択治療法と し，その完全摘除が困難な場合や手術に伴う損 傷を避けるために保存的治療を行うとするもの と，ブレオマイシンや OK-432 の局所投与によ る治療を第一選択として推奖するものとに分か れている2627). 今後 OK-432 局注療法の上らに, 重篤な副作用が無く, 完全消退率が高く, 治療 期間が短く, 治療部位に障害を残さない侵襲度 の低い優れた治療法の適応が，成人のリンパ管 腫にも検討されるものと考える。

\section{おわりに}

本症例では肉眼的に処理した範囲で複雑に引 き延ばされた下顎縁枝を切断してしまった．幸 いなことに顕微鏡下に処理した煩枝が保存され 顔面神経麻㿁は下口唇の一部分のみで日常生活 に支障なく，患者も下顎縁枝の神経縫合の結果 を待つことを了解したが，この失敗は比較的早 い時期から顕微鏡下の手術に切り替えておけば 防げたものであろらと反省している. 手術の正 確さと完全摘出が特に要求された本症例では顕 微鏡の使用は不可欠の物であった．顕微鏡下の 手術は時間がかかるものであるが，不必要な血 管の損傷が未然に防げ，耳下腺手術に特有の視 野を妨げる出血に悩まされる事もなく, 場合に 応じて神経上膜の切除さえ容易に行えた. 縫合 した下顎縁枝の麻痺は術後 3 カ月で完全に回復 
した. 術後 1 年 10 カを経た現在, 腫瘍の再発 は認められない。

$$
\text { まとめ }
$$

1 ）成人の耳下腺囊胞状リンパ管腫症例につい て報告した。

2 ) 本腫瘍は軟部組織への進入傾向が強く顔 面神経の保存が困難になる場合が多いとされて いるが，手術用顕微鏡を用いることにより, 裸 眼では剥離不可能と思われた部分でも比較的容 易に剥離が行える。

恩師, 秋田大学医学部耳鼻咽喉科学教室戸川 清 教授の御指導・御校閲に感謝致します, 尚, 本論文 の要旨は第52回日耳鼻秋田県地方部会学術講演会に おいて講演された。

\section{参考文献}

1）勝俣慶三：先天性裂腫。リンパ管腫. 外科 Mook $7:$ 15 29, 1979.

2) Kennedy TL : Cystic hygroma-lymphangioma ; a rare and still unclear entitiy. Laryngoscope 99 suppl $49: 1 \sim 10,1989$.

3) Schefter RP, Olsen KD and Jaffey TA : Cervical lymphangioma in the adult. Otolaryngol Head Neck Surg 93 : 65 69, 1985.

4) Karmody CS : Lymphangiomas of the head and neck in adults. Otolaryngol Head Neck Surg $90:$ 283 288, 1982.

5) Baer $\mathrm{S}$ : Cystic hygroma presenting in adulthood. J of Laryngol Otol 103 : 976 977, 1989.

6）矢野原邦生, 加藤昭彦, 宮原幸則, 他: 成人の 頓部リンパ管腫症例. 耳鼻臨床 $81 ： 1477 \sim 1482$, 1988.

7）加藤雄一, 夜久有滋, 網 幸一, 他: 成人に2 られた上咽頭珵状リンパ管腫例. 耳鼻臨床 83 ： 415 419, 1990.

8）大津一弘, 中野豊道, 東 信隆, 他: 成人の頸 部裂腫性リンパ管腫の 1 例。広島医学 42： 1312 1314, 1989.

9）戸川 清：耳下腺腫瘍手術の要領と顔面神経の 処理. 耳下腺腫瘍の臨床（奥田 稔編）。142 159頁, 医学教育出版社, 東京, 1984.
10）西平茂樹：運動神経修復に関する実験的研究 一フィブリン糊とナイロン系による修復法の比

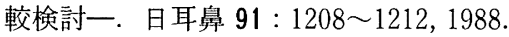

11）沼田 稔, 安里 進, 細江志郎, 他: 成人女子 にみられた頸部褧腫性リンパ管腫の 1 例. 外科 $43: 1500 \sim 1504,1978$.

12）北村 武：耳下腺腫瘍の臨床像. 耳下腺腫瘍の 臨床（奥田 稔編）．61～86頁, 医学教育出版 社, 東京, 1984 .

13）金子敏郎，石毛俊行：耳下腺腫瘍の治療. 医学 のあゆみ $153: 77,1990$.

14) Anderson DH : Tumors of infancy and childhood. Cancer $4:$ 890 906, 1951.

15) Skandalakis JE : Embryology for surgeons (Ch. 22). pp 960 970, WB Saunders Co., Philadelphia, 1953.

16) Gupta B : Incidence of congenital malformation in Nigerian children. West Afr Med J $18: 22,1969$.

17) Wright GL : Benign parotid diseases of childhood. Laryngoscope 95 : 915 920, 1985.

18) Crawford AP : Lymphangioma of the parotid gland. Med J Aust 2 : 141 142, 1981.

19) Ferguson MM : Ulutrasonography in the diagnosis of a cystichygroma. Int J Oral Surg 6:229 232, 1977.

20) Bill AH Jr and Sumner DS : A unified concept of lymphangioma and cystichygroma. Surg Gynecol Obstet 120:79 86, 1965.

21) Sarno RC : Cystic lymphangiomas; CT diagnosis and thin needle aspiration. B J Radiol 57 : 424 426, 1984.

22) Stenson KM, Mishell J and Toriumi DM : Cystic hygroma of the parotid gland. Ann Otol Rhinol Laryngol 100 : 518 520, 1991.

23) Som PM : Salivary Gland. Head and Neck Imaging (ed by Som PM and Bergron RT). pp 277 347, Mosby Year Book, St Louis, Missouri, 1991.

24）世良好史, 吉村実信, 池田信二, 他 : 娸胞状リ ンパ管腫の診断と治療の要点. 小児外科 12 : 1587〜1591, 1980.

25）戸谷拓士：巨大な側頸部腫瘤をもつ新生児. 小 児外科 $20: 1543 \sim 1546,1988$. 
26）高戸 毅：ブレオマイシン注入による整胞状リ ンパ管腫の治療. 形成外科 $31: 752 \sim 756,1988$.

27）荻田修平, 伝 俊秋, 出口英一, 他：リンパ管 腫の治療 一外科切除, Bleomycin 局注療法, OK-432 局注療法の比較検討一. 日本外科学会
雑誌90：1389～1391, 1989.

(別刷請求先 : 西平茂樹 厂012 湯沢市表町3-3-15 雄勝中央病院耳鼻咽喉科 